\title{
UNINTENDED CONSEQUENCES: THE SUPREME COURT'S INTERPRETATION OF THE SECOND AMENDMENT IN District of COLumbia V. Heller COUld WATER- DOWN FOURTH AMENDMENT RIGHTS
}

\begin{abstract}
BY GEORGE M. DERY III*
"[I]f watering-down is the mood of the day, I would prefer to water down the Second rather than the Fourth Amendment."

- Justice William O. Douglas

\section{INTRODUCTION}

The United States Supreme Court recognizes the practical effects, even the life and death consequences, of its decisions. In Terry v. Ohio, the seminal Fourth Amendment ${ }^{2}$ case that recognized an officer's right to perform a stop and frisk, ${ }^{3}$ the Court explicitly acknowledged the concern that frisking a suspect "was essential to the proper performance of the officer's investigatory duties," because without such a right to search, "the answer to the police officer may be a bullet." Recognizing the "practical" issues implicated by a police stop and frisk, the Court in Terry paid heed
\end{abstract}

\footnotetext{
* Professor, California State University Fullerton, Division of Politics, Administration, and Justice; former Deputy District Attorney, Los Angeles, California; J.D. 1987, Loyola Law School, Los Angeles; B.A. 1983, University of California Los Angeles. I would like to thank my research assistant, Jonathan Demers, B. A. 2008, Criminal Justice, California State University Fullerton.

${ }^{1}$ Adams v. Williams, 407 U.S. 143, 151 (1972) (Douglas, J., dissenting).

${ }^{2}$ U.S. CONST. amend. IV ("The right of the people to be secure in their persons, houses, papers, and effects, against unreasonable searches and seizures, shall not be violated, and no Warrants shall issue, but upon probable cause, supported by Oath or affirmation, and particularly describing the place to be searched, and the persons or things to be seized."). ${ }^{3}$ Terry v. Ohio, 392 U.S. 1, 30-31 (1967) (finding that evidence seized during a stop-andfrisk is admissible if the police officer has reasonable suspicion that the individual was armed and dangerous and restricts search to the pat down of outer clothing for weapons). ${ }^{4}$ Id. at 8 .
} 
to the argument that, "[i]n dealing with the rapidly unfolding and often dangerous situations on city streets, the police are in need of an escalating set of flexible responses." The Terry Court further considered that a ruling could be potentially "powerless" in affecting police behavior if an officer was "willing to forgo [sic] successful prosecution in the interest of serving some other goal." Another goal that an officer might have besides bringing a criminal in to book could be simply to survive the encounter.

The Court's concerns for officer safety have therefore had a direct impact on Fourth Amendment rights. Case law has repeatedly referred to the prospect of gun violence as justification for extending officers' powers at the expense of individual rights against unreasonable search and seizure. Such decisions are not without controversy; some legal commentators decry the diminution of Fourth Amendment protections, ${ }^{7}$ while others doubt the suitability of its most powerful remedy, the exclusionary rule. ${ }^{8}$

Of course, the Fourth Amendment is hardly the only constitutional right to generate conflict between competing concerns. In the Second Amendment context, ${ }^{9}$ a long-running debate has developed between those who interpret the right to keep and bear arms as a collective right needed only to establish militias, ${ }^{10}$ and those who see the right to bear arms as an individual right required to check tyranny. ${ }^{11}$ The individual right view

\footnotetext{
${ }^{5} I d$. at 10 .

${ }^{6} I d$. at 14 .

${ }^{7}$ See Aya Gruber, Garbage Pails and Puppy Dog Tails: Is that What Katz Is Made of? 41 U.C. DAVIS L. REV. 781 (2008).

${ }^{8}$ See Akhil Reed Amar, Fourth Amendment First Principles, 107 HARV. L. REV. 757 (1994).

9 The Second Amendment provides, "A well regulated Militia, being necessary to the security of a free State, the right of the people to keep and bear Arms, shall not be infringed." U.S. CONST. amend. II.

${ }^{10}$ See District of Columbia v. Heller, 128 S. Ct. 2783, 2845 (Stevens, J., dissenting) ("The Miller Court unanimously concluded that the Second Amendment did not apply to the possession of a firearm that did not have 'some reasonable relationship to the preservation or efficiency of a well regulated militia.'”).

${ }^{11}$ The Heller Court quoted Thomas Cooley, a legal scholar, judge, and professor, who declared in an 1868 Treatise on Constitutional Limitations, "Among the other defenses to personal liberty should be mentioned the right of the people to keep and bear arms." Id. at 2811 (majority opinion). Thomas Cooley also wrote that the Second Amendment was "adopted with some modification and enlargement from the English Bill of Rights of
} 
won a decisive victory in the 2008 Supreme Court case, District of Columbia $v$. Heller. ${ }^{12}$ The Court in Heller was presented with two very different interpretations of the Second Amendment. ${ }^{13}$ The government argued that the Second Amendment protects "only the right to possess and carry a firearm in connection with militia service." 14 Dick Heller, in contrast, asserted that the constitutional provision protects "an individual right to possess a firearm unconnected with service in the militia, and to use that [fire]arm for traditionally lawful purposes, such as self-defense within the home." 15 The Heller Court sided with Dick Heller's individual rights view of the Second Amendment, holding that "the District's ban on handgun possession in the home violates the Second Amendment."

However, individual rights cannot be viewed in a vacuum. The characterization of the Second Amendment as an individual right may lead to further erosion of individual privacy and security rights protected by the Fourth Amendment. As the Court in Heller acknowledged, "the enshrinement of constitutional rights necessarily takes certain policy choices off the table." ${ }^{\prime 17}$ Thus, a practical consequence of Heller might be a limitation of the government's options to address gun violence. As a result, police officers, finding themselves less protected by gun control legislation, may resort to self-help by committing more frequent or more intrusive searches or seizures. Therefore, the Court, mindful of the danger to officers posed by firearms, may hesitate in the future to maintain current Fourth Amendment protections.

This Article will not perform an analysis of the Second Amendment or its accompanying precedent. Instead, it examines the possibility that, because of the promotion of the individual right to keep and bear arms, the Court might develop legal rules that ultimately limit individual protections under the Fourth Amendment. In Part II, this article will address legal scholarship, which contends that recognition of the Second

1688, where it stood as a protest against arbitrary action of the overturned dynasty in disarming the people." Id. at 2811.

${ }^{12}$ Id. at 2821-22.

${ }^{13}$ Id. at 2789 .

${ }^{14} I d$.

${ }^{15}$ Heller, 128 S. Ct. at 2789.

${ }^{16}$ Id. at 2821 .

${ }^{17}$ Id. at 2822. 
Amendment as an individual right is proper and necessary to promote individual freedoms. Part III will summarize the Heller case and its holding. Part IV will examine the possibility that the Court's expansion of Second Amendment freedoms may compel a contraction of Fourth Amendment privacy and security rights during police encounters on the street, arrests, and home intrusions by police.

\section{BaCkground: The Call to Recognize the Second AMENDMENT AS AN INDIVIDUAL RIGHT}

Commentators have made thoughtful and impassioned arguments calling on the Court to interpret the Second Amendment's right to bear arms as an individual right. Sanford Levinson, a pioneer in Second Amendment analysis, referred to the Second Amendment as an "ignored patch of text in our constitutional conversations"18 because "most members of the legal academy have treated the Second Amendment as the equivalent of an embarrassing relative, whose mention brings a quick change of subject to other, more respectable family members." 19

Levinson noted the contrast between the silence of legal commentators and Senator Orrin Hatch (R-Utah), who deemed the right to keep and bear arms "the most valued by free men." ${ }^{20}$ In addition, Levinson highlighted the words of James Madison, who stated in Federalist No. 46 that "the advantage of being armed, which the Americans possess over the people of almost every other nation," enables Americans to protect their political liberty. ${ }^{21}$ Moreover, commentator Scott Henderson quoted Federalist author, Alexander Hamilton, because of his similar logic regarding the individual right to bear arms. Hamilton argued that, "[i]f representatives of the people betray their constituents, there is then no

\footnotetext{
18 Sanford Levinson, The Embarrassing Second Amendment, 99 YALE L.J. 637, 640 (1989).

${ }^{19} I d$. at 658 .

${ }^{20} \mathrm{Id}$. at 641 .

${ }^{21}$ Id. at 648-49 (quoting THE Federalist No. 46, at 299 (James Madison) (Clinton Rossiter ed., 1961)).
} 
recourse left but in the exertion of that original right to self defense which is paramount to all positive forms of government. $" 22$

During state conventions, where members debated the ratification of a bill to recognize individual rights against the government, protection of the right to arms was a prominent issue. For example, at the Virginia Convention, American icon of liberty, Patrick Henry, warned that all should "[g]uard with jealous attention the public liberty. Suspect every one who approaches the jewel. Unfortunately, nothing will preserve it but downright force. Whenever you give up that force, you are ruined."23 Henry offered as a solution "that every man be armed." 24 One scholar, Jerry Bonanno, considered the "unique relationship between firearms and the American citizen" to be the result of the formation of the American character. ${ }^{25}$ Bonanno pointed out that the United States "was born in a violent, armed assertion of its national independence," and noted that "early Americans pushed West into a violent frontier before there was any semblance of government protection." ${ }^{\prime 2}$ This historical background "explains why the right to keep and bear arms plays such an important role in American Society." 27

Moreover, modern legal commentators have found further support for a robust individual right to keep and bear arms in the writings of Supreme Court Justice Joseph Story. ${ }^{28}$ In his 1833 Commentaries on the Constitution of the United States, Justice Story characterized the Second

22 See Scott A. Henderson, United States v. Emerson: The Second Amendment as an Individual Right-Time to Settle the Issue? 102 W. VA. L. REV. 177, 190 (1999) (quoting The Federalist No. 28, at 180 (Alexander Hamilton) (Arlington House ed., n.d.)).

${ }^{23}$ See Stephen B. Halbrook, That Every Man Be Armed 73 (2d ed. 1994) (citing 3 Jonathan Elliot, Debates in the Several State Conventions 45 (2d ed. 1836)).

${ }^{24}$ Henderson, supra note 22, at 193. Henderson also quoted Thomas Jefferson, who declared that "no free man shall be debarred the use of arms in his own hands" and advised his nephew to "[l] et your gun therefore be the constant companion on your walks." See $\mathrm{id}$. at 201-02 (quoting ThE JefFERSONIAN CyClOPEDIA 51, 318 (Foley ed., reissued 1967)).

${ }^{25}$ Jerry Bonanno, Facing the Lion in the Bush: Exploring the Implications of Adopting an Individual Rights Interpretation of the Second Amendment to the United States Constitution, 29 HAMLINE L. REV. 461, 499 (2006).

${ }^{26} I d$.

${ }^{27}$ Id. at 500 .

${ }^{28}$ Henderson, supra note 22, at 204. 
Amendment's "right of the citizens to keep and bear arms" to be "the palladium of the liberties of a republic ... since it offers a strong moral check against the usurpation and arbitrary power of rulers." ${ }^{29}$ One commentator has even speculated whether "the brutal suppression of the Chinese student demonstrations in Tiananmen Square" would have been possible if all Chinese citizens had kept arms. ${ }^{30}$

Justice Story described the Second Amendment as an "auxiliary" right" that would enable "citizens to retrieve their Government from the hands of unjust and despotic rulers." "31 Also, Judge Kozinski characterized the Second Amendment as a:

doomsday provision, one designed for those exceptionally rare circumstances where all other rights have failedwhere the government refuses to stand for reelection and silences those who protest; where courts have lost the courage to oppose, or can find no one to enforce their decrees. However improbable these contingencies may seem today, facing them unprepared is a mistake a free people get to make only once. ${ }^{32}$

Arguing that the Second Amendment be considered an individual right, commentator Ronald H. Beason asked, "[a]re we ready to give up our rights?" and further declared, "[t]he people are waiting." 33

\footnotetext{
${ }^{29} I d$. (emphasis in original).

${ }^{30}$ Levinson, supra note 18, at 656-57 (quoting Wimmershoff-Caplan, The Founders and the AK-47, WASH. Post, July 6, 1989, at AI8, col. 4, reprinted as Price of Gun Deaths Small Compared to Price of Liberty, Austin Am.-STATESMAn, July 11, 1989, at All).

${ }^{31}$ Christopher A. Chrisman, Mind the Gap: The Missing Standard of Review Under the Second Amendment (and Where to Find It), 4 GEO. J.L. \& PUB POL'Y 289, 301 (2006) (quoting JOSEPH STORY, COMMENTARIES ON THE CONSTITUTION § 1001 (1987)).

${ }^{32} I d$. (quoting Silveira v. Lockyer, 328 F.3d 567, 570 (2003) (Kozinski, J., dissenting)).

${ }^{33}$ Roland H. Beason, Printz Punts on the Palladium of Rights: Is It Time to Protect the Right of the Individual to Keep and Bear Arms?, 50 ALA. L. REV. 561, 561, 584 (1999).
} 


\section{The COURT's IDENTIFICATION OF THE Right TO KeEP AND BEAR ARMS AS AN INDIVIDUAL RIGHT IN DISTRICT OF COLUMBIA V. HELLER}

The calls by these legal commentators for the recognition of the Second Amendment as an individual right were answered in Heller, in which the Court considered Washington D.C.'s gun laws. ${ }^{34}$ The District of Columbia's gun restrictions included strict provisions, which criminalized the carrying of unregistered firearms, limited licensing of firearms, and required residents to keep lawfully owned firearms "unloaded and dissembled or bound by a trigger lock or similar device" in various circumstances. ${ }^{35}$ After being refused registration for a handgun to keep at home, Dick Heller sued in federal court on Second Amendment grounds. ${ }^{36}$ The Court, in an opinion written by Justice Scalia, used the case as a vehicle to perform "this Court's first in-depth examination of the Second Amendment.",37

Justice Scalia noted that opposing parties offered "very different interpretations of the Amendment." 38 The government argued that the Second Amendment created a collective "right to possess and carry a firearm in connection with militia service." 39 In contrast, Heller contended that the Second Amendment "protects an individual right to possess a firearm unconnected with service in a militia, and to use that arm for traditionally lawful purposes, such as self-defense within the home." ${ }^{\text {"Th }}$ The Court sided with the gun owner and held that "the District's ban on handgun possession in the home violates the Second Amendment, as does

\footnotetext{
${ }^{34}$ Heller, 128 S.Ct. at 2788.

${ }^{35}$ Id. (quoting D.C. CODE $§ 7-2507.02$ (2001)).

${ }^{36}$ Heller sued to "enjoin the city from enforcing the bar on the registration of handguns, the licensing requirement insofar as it prohibits the carrying of a firearm in the home without a license, and the trigger-lock requirement insofar as it prohibits the use of "functional firearms within the home." Id.

${ }^{37}$ Id. at 2821.

${ }^{38}$ Id. at 2789.

${ }^{39}$ Heller, 128 S. Ct. at 2789.

${ }^{40} \mathrm{Id}$.
} 
its prohibition against rendering any lawful firearm in the home operable for the purpose of immediate self-defense." 41

The Court reached this conclusion by first analyzing the text of the Second Amendment. ${ }^{42}$ Specifically, the Court in Heller noted that the Second Amendment codified a "right of the people." ${ }^{.43}$ Justice Scalia highlighted that the "unamended Constitution and the Bill of Rights use the phrase 'right of the people' two other times, in the First Amendment's Assembly-and-Petition Clause and in the Fourth Amendment's Searchand-Seizure Clause., ${ }^{44}$ In both instances, the right of the people refers to individual rights. ${ }^{45}$ This phrasing, as well as other "textual elements," led the Court to find that the Second Amendment guaranteed "the individual right to possess and carry weapons in case of confrontation." 46

Further, to fully understand the purpose of the Second Amendment, the Court explored the interplay of militias and gun rights in $17^{\text {th }}$ century England, a period that had a significant influence on the Framers. ${ }^{47}$ Justice Scalia viewed this history to demonstrate that the Second Amendment did not create an individual right, but "codified a preexisting right." ${ }^{\text {" }}$ The Court in Heller noted that, "[b]etween the Restoration and the Glorious Revolution, the Stuart Kings Charles II and James II succeeded in using select militias loyal to them to suppress political dissidents, in part by disarming their opponents;" therefore, the Stuart Kings recognized that these "experiences caused Englishmen to be extremely wary of concentrated military forces run by the state and to be jealous of their arms." ${ }^{49}$ Thus, Englishmen "obtained an assurance from William and Mary, in the Declaration of Right" against individuals being

${ }^{41} I d$. at 2821-22.

${ }^{42} \mathrm{Id}$. at 2788 .

${ }^{43} I d$. at 2790.

${ }^{44}$ Heller, 128 S. Ct. at 2790.

${ }^{45} \mathrm{Id}$.

${ }^{46} \mathrm{Id}$. at 2797.

47 Id. at 2798. See generally Michael BARONe, Our First Revolution: The

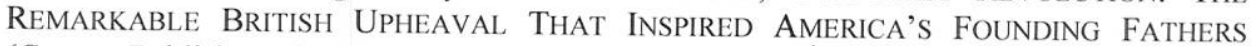
(Crown Publishers 2008) (exploring the impact of $17^{\text {th }}$ century English history and politics on the thinking of the Founding Fathers).

${ }^{48}$ Heller, 126 S. Ct. at 2797 (emphasis in original).

${ }^{49}$ Id. at 2798. 
disarmed. ${ }^{50}$ The Court in Heller concluded that this right "has long been understood to be the predecessor to our Second Amendment." ${ }^{, 51}$ Moreover, the Court cited Blackstone for the proposition that the right to keep and bear arms was among the "fundamental rights of Englishmen" and a "natural right of resistance and self-preservation." 52 George III himself, during the "tumultuous decades of the 1760s and 1770s," began to "disarm the inhabitants of the most rebellious areas" of the colonies. ${ }^{53}$ Americans of the late $18^{\text {th }}$ century understood the "right of self-preservation' as permitting a citizen to 'repe[1] force by force' when 'the intervention of society in his behalf, may be too late to prevent an injury." ${ }^{54}$ Thus, Justice Scalia concluded that, "on the basis of text and history ... the Second Amendment conferred an individual right to keep and bear arms." ${ }^{.55}$

Moreover, the Court in Heller also considered the opinions of three "founding-era legal scholars," all of which interpreted the Second Amendment to protect "an individual right unconnected with militia service. ${ }^{, 56}$ In St. George Tucker's version of Blackstone's Commentaries, the right to bear arms was "necessary for self defense," which was "the first law of nature." ${ }^{, 57}$ In addition, it had been "the study of rulers to confine the right within the narrowest limits possible. Wherever standing armies are kept up, and the right of the people to keep and bear arms is, under any colour or pretext whatsoever, prohibited, liberty, if not already annihilated, is on the brink of destruction., 58

In addition, the Court highlighted the words of abolitionists and political leaders who spoke about the right to bear arms during the Reconstruction Era. Justice Scalia noted that "[a]ntislavery advocates routinely invoked the right to bear arms for self-defense." ${ }^{, 59}$ A Congressman discussing the passage of the Civil Rights Act of 1871 and the

${ }^{50} I d$.

${ }^{51} \mathrm{Id}$.

${ }^{52}$ Id. (quoting 1 William Blackstone, COMMENTARIES 136, 139-40 (1765)).

${ }^{53} I d$. at 2799.

${ }^{54}$ Heller, 128 S. Ct. at 2799 (quoting 1 Blackstone's Commentaries 145-46, n.42 (1803)).

${ }^{55} I d$.

${ }^{56}$ Id. at 2805 .

${ }^{57}$ Id. (quoting 2 BLACKSTONE's COMMENTARIES 143 (1803)).

${ }^{58}$ Id.

${ }^{59}$ Heller, 128 S. Ct. at 2807. 
Fourteenth Amendment saw these laws as, in part, enforcing "the wellknown constitutional provision guaranteeing the right of the citizen to "keep and bear arms." ",60 A U.S. Senator during the Reconstruction period went so far as to deem "one of the three 'indispensible' 'safeguards of liberty ... under the Constitution' a man's 'right to bear arms for the defense of himself and family and his homestead."'61

Thus, in some of the noblest endeavors of our history-the Founder's fight for independence against the oppressive Crown in England, the formation of our national charter by the Framers, the fight to abolish slavery, and the passage of civil rights legislation and the Fourteenth Amendment - the right to keep and bear arms was an important aspect of political and legal debates. The Second Amendment codified an individual right to keep and use firearms, served as a fundamental freedom to rely on if the government took all other liberties away, and formed an indispensable part of the expansion of freedom in England and America.

\section{HelleR's Potential Limits on Fourth AMENdment Rights}

A. The Court's Changing Treatment of the Exclusionary Rule in the Fourth Amendment Context Shows How Characterization of a Rule as an Individual Right Has Practical Consequences

The Court in Heller took pains to allay fears about the implications of its ruling. Justice Scalia stated that, "[1]ike most rights, the right secured by the Second Amendment is not unlimited." ${ }^{\circ 2}$ The Court concluded that:

nothing in our opinion should be taken to cast doubt on longstanding prohibitions on the possession of firearms by felons and the mentally ill, or laws forbidding the carrying of firearms in sensitive places such as schools and gov-

\footnotetext{
${ }^{60} I d$. at 2810, 2811 (quoting. H.R. REP. NO. 41-37, at 7-8 (1871)).

${ }^{61} I d$. at 2811 (quoting CONG. GlOBE, 39th Cong., 1st Sess. 1182 (1866)).

${ }^{62}$ Heller, 128 S. Ct. at 2816.
} 
ernment buildings, or laws imposing conditions and qualifications on the commercial sale of arms. ${ }^{63}$

Yet, at the same time, the Court in Heller recognized that, "the enshrinement of constitutional rights necessarily takes certain policy choices off the table."

Recognition of a rule as a constitutional right does, indeed, have significant practical consequences. It certainly did in the Fourth Amendment case, Mapp v. Ohio, where the Court adopted the exclusionary rule. ${ }^{65}$ In Mapp, the Court, in an opinion authored by Justice Clark, held that "all evidence obtained by searches and seizures in violation of the Constitution is, by that same authority, inadmissible in a state court." ${ }^{, 66}$ In support of its ruling, the Court characterized the exclusionary rule as "an essential part of both the Fourth and Fourteenth Amendments." "67 Justice Clark reasoned that it was "logically and constitutionally necessary that the exclusion doctrine - an essential part of the right to privacy-be also insisted upon as an essential ingredient" of the right against unreasonable search and seizure. $^{68}$ To hold otherwise, the Court asserted, would be to "grant the right but in reality to withhold its privilege and enjoyment."

However, in future case, when the Court carved out exceptions to the exclusionary rule, it dismantled Mapp's recognition of the exclusionary rule as a constitutional right. Specifically, in United States $v$. Calandra, the Court prohibited a grand jury witness from invoking the exclusionary rule to avoid questions that were based on evidence obtained in violation of the Fourth Amendment. ${ }^{70}$ In support of its ruling to limit

${ }^{63}$ Id. at $2816-17$.

${ }^{64} \mathrm{Id}$. at 2822.

${ }^{65}$ Mapp v. Ohio, 367 U.S. 643 (1961).

${ }^{66} \mathrm{Id}$. at 655 .

${ }^{67}$ Id . at 657 . The Fourteenth Amendment provides in pertinent part that, "No State shall ... deprive any person of life, liberty, or property, without due process of law." U.S. CONST. amend. XIV.

${ }^{68}$ Mapp, 367 U.S. at 656.

${ }^{69}$ Id. But see Potter Stewart, The Road to Mapp v. Ohio and Beyond: The Origins, Development and Future of the Exclusionary Rule in Search-and-Seizure Cases, 83 COLuM. L. REV. 1365 (1983) (criticizing the Mapp opinion as unclear regarding the source of the exclusionary rule).

${ }^{70}$ United States v. Calandra, 414 U.S. 338, 354-55 (1973). 
the application of the exclusionary rule, the Calandra Court rejected the rationale in Mapp and called the exclusionary sanction a mere "judicially created remedy designed to safeguard Fourth Amendment rights generally through its deterrent effect, rather than a personal constitutional right of the party aggrieved." device, the application of the rule has been restricted to those areas where its remedial objectives are thought most efficaciously served." 72 Two years later, the Court employed the reasoning of Calandra in United States v. Janis ${ }^{73}$ where the Court admitted evidence in a federal civil proceeding which was "unlawfully seized by a state criminal enforcement officer." 74

In an effort to further avoid the exclusionary rule's unpleasant consequences, the Court even cast doubt on the rule's function as a remedy. In Stone v. Powell, the Court asserted not only that the exclusionary rule was "not a personal constitutional right," but also that the rule failed to provide a remedy to the victim of a Fourth Amendment violation. The Court pointed out that the rule fails to provide a remedy because "[i]t is not calculated to redress the injury to the privacy of the victim of the search or seizure, for any "[r]eparation comes too late.","75 Privacy could not be returned and persons and things could not be un-seized. Therefore, the exclusionary rule's "primary justification" was to deter police from future illegal searches. ${ }^{76}$ As a result, the Court concluded that if the deterrent effect of exclusion was uncertain or its deterrent effect was outweighed by its societal costs, then the exclusionary rule should not be implemented. ${ }^{77}$

The Court has gone so far as to deem the exclusionary rule merely "prudential rather than constitutionally mandated." ${ }^{.78}$ The repeated demotion of the exclusionary rule from a constitutional right to a judiciallycreated remedy, and, ultimately, to a prudential rule has allowed this sanction to be continually avoided. A partial listing of the exceptions to

${ }^{71} I d$. at 348 .

${ }^{72} I d$.

${ }^{73}$ United States v. Janis, 428 U.S. 433, 446 (1976).

${ }_{75}^{74} \mathrm{Id}$. at 454.

${ }_{76}^{75}$ Stone v. Powell, 428 U.S. 465, 486 (1975).

${ }^{76} \mathrm{Id}$.

${ }^{77} \mathrm{Id}$. at $487-89$.

${ }^{78}$ Pa. Bd. of Prob. \& Parole v. Scott, 524 U.S. 357, 363 (1998). 
the exclusionary rule demonstrates the damage. The Court has prevented the exclusionary rule from suppressing illegally-obtained evidence in the following situations: when impeaching a defendant's testimony ${ }^{79}$ where the government is introducing evidence at a parole revocation hearing, ${ }^{80}$ when officers relied in good faith on a search warrant, ${ }^{81}$ or where police relied on a computer's representation of the existence of an arrest warrant. $^{82}$ This dramatic devolution of the exclusionary rule as a means to protect Fourth Amendment rights demonstrates that recognizing a rule as an individual constitutional guarantee has practical outcomes. The inverse might easily occur with the Second Amendment: recognition of the right to keep and bear arms as an individual right could create practical limits on the government's ability to control guns. ${ }^{83}$

\section{B. The Ruling in Heller May Accelerate an Erosion of Fourth Amendment Rights during Police Stop and Frisks}

The idea, expressed in Heller, that expanding one right promotes freedom in general might be too simplistic. A nation of individuals with access to firearms does indeed put government officials on notice, but the resulting consequences may lead to gradual limitations on freedom. Specifically, the impact on individual rights when a government is dealing with a potentially armed populace was dramatically illustrated in the seminal Fourth Amendment case, Terry v. Ohio. ${ }^{84}$ In Terry, on Halloween in 1963, Cleveland Police Detective Martin McFadden noticed two men, Chilton and Terry, behaving very peculiarly, which caused him to suspect that the men were planning "a stick up" of a store. ${ }^{85}$ Fearing that "they might have a gun," Officer McFadden approached the two men, identified himself, and asked for their names. ${ }^{86}$ When the men "mumbled" their responses, McFadden spun Terry around, patted down the outside of his

${ }^{79}$ See Oregon v. Hass, 420 U.S. 714 (1975).

${ }^{80} \mathrm{See}$ Pa. Bd. of Prob., 524 U.S. at 359.

${ }^{81}$ See United States v. Leon, 468 U.S. 897, 926 (1984).

${ }^{82}$ See Arizona v. Evans, 115 S. Ct. 1185, 1194 (1995).

${ }^{83}$ Heller, 128 S. Ct. at 2822.

${ }^{84}$ Terry v. Ohio, 392 U.S. 1 (1968).

${ }^{85} \mathrm{Id}$. at $5-6$.

${ }^{86} \mathrm{Id}$. at 6-7. 
clothing, felt a pistol, and ultimately recovered from his breast pocket a .38 caliber revolver. ${ }^{87}$

The facts in Terry presented the Court with "difficult and troublesome issues" concerning a "sensitive area of police activity"- the stop and frisk. ${ }^{88}$ On the one hand, Chief Justice Warren, writing for the Court, emphasized that the Fourth Amendment right against unreasonable search and seizure was an "inestimable right of personal security" that belonged "as much to the citizen of the streets of our cities as to the homeowner closeted in his study. ${ }^{, 89}$ Specifically, the Court declared that "no right is held more sacred, or is more carefully guarded, by the common law, than the right of every individual to the possession and control of his own person...." Cognizant of the realities of police encounters with civilians on the street, the Court noted that such police activity could "exacerbate police-community tensions," interrogations are a major source of friction between the police and minority groups." ${ }^{.92}$ Chief Justice Warren considered the negative effects that street detentions might cause in the hands of an unprofessional officer, who may be motivated by "the need to maintain the power image of the beat officer, an aim sometimes accomplished by humiliating anyone who attempts to undermine police control of the streets." ${ }^{.93}$

However, the Court in Terry considered, on the other hand, that "the rapidly unfolding and often dangerous situations on city streets" required giving police "an escalating set of flexible responses" "94 to ensure their safety. Chief Justice Warren recognized that officers performing field detentions have an interest more immediate and fundamental than the investigation of crime: the interest in surviving the encounter. ${ }^{95}$ The Court

${ }^{87} I d$. at 7 .

${ }^{88} \mathrm{Id}$. at 9-10.

${ }^{89}$ Terry, 392 U.S. at 8-9.

${ }^{90} \mathrm{Id}$.

${ }^{91} I d$. at 12 .

${ }^{92}$ Id. at 15 n. 11 .

${ }^{93} I d$.

${ }^{94}$ Terry, 392 U.S at 10. The Court viewed the stop and frisk in the field as "an entire rubric of police conduct" that necessitated "swift action." Id. at 20.

${ }^{95}$ Id. at 23 ("We are now concerned with more than the governmental interest in investigating crime; in addition, there is the more immediate interest of the police officer 
stated, "American criminals have a long tradition of armed violence, and every year in this country many law enforcement officers are killed in the line of duty, and thousands more are wounded." 96 The Court made an explicit connection between guns and officer fatalities, specifying that "[f]ifty-five of the 57 officers killed in 1966 died from gunshot wounds, 41 of them inflicted by handguns easily secreted about the person." 97 The Court continued, "[t]he easy availability of firearms to potential criminals in this country is well known and has provoked much debate." ${ }^{.98}$ The Court then specifically linked gun violence to its ruling by declaring, "[w] hatever the merits of gun-control proposals, this fact is relevant to an assessment of the need for some form of self-protective search powers." 99

The subsequent legal rule allowed police to perform a stop and frisk for weapons for the protection of the police officer when "he has reason to believe that he is dealing with an armed and dangerous individual, regardless of whether he has probable cause to arrest the individual for a crime." 100 As for the scope of the police search, the Court found reasonable an officer's pat down, ${ }^{101}$ or a "carefully limited search" of "outer clothing" in order to "discover weapons which might be used against him."102

The Terry Court recognized that its rule was novel, admitting that "[w]e would be less than candid if we did not acknowledge that his question thrusts to the fore difficult and troublesome issues regarding a sensitive area of police activity-issues which have never before been squarely presented to this Court." 103 Moreover, the Court realized the significance of its extension of police search powers. Chief Justice Warren flatly stated,

in taking steps to assure himself that the person with whom he is dealing is not armed with a weapon that could unexpectedly and fatally be used against him.").

${ }^{96} \mathrm{Id}$. at 23 .

97 Id. at 23-24 n.21. Furthermore, the Court went beyond homicides to examine the broader cost of violence against police, noting that "in 1966, there were 23,851 assaults on police officers, 9,113 of which resulted in injuries to the policemen." Id.

${ }^{98} \mathrm{Id}$. at 24 n.21.

${ }^{99}$ Terry, 392 U.S. at 24 n.21.

${ }^{100} \mathrm{Id}$. at 27.

${ }^{101} \mathrm{Id}$. at 29.

${ }^{102} \mathrm{Id}$. at 30.

${ }^{103} \mathrm{Id}$. at $9-10$. 
it is simply fantastic to urge that [a frisk] performed in public by a policeman while the citizen stands helpless, perhaps facing a wall with his hands raised, is a "petty indignity.' It is a serious intrusion upon the sanctity of the person, which may inflict great indignity and arouse strong resentment, and it is not to be undertaken lightly. ${ }^{104}$

The Court cited the following as an "apt description" of a frisk: "[t]he Officer must feel with sensitive fingers every portion of the prisoner's body. A thorough search must be made of the prisoner's arms and armpits, waistline and back, the groin and area about the testicles, and entire surface of the legs down to the feet." ${ }^{, 105}$ Despite its intrusiveness, the Court justified upholding the government's new right to search by declaring, "we cannot blind ourselves to the need for law enforcement officers to protect themselves and other prospective victims of violence in situations where they may lack probable cause for an arrest." 106

The Court's concern for officer safety, specifically against the threat of firearms, was voiced again in Adams v. Williams. ${ }^{107}$ In Adams, Justice Rehnquist, writing for the Court, took care to describe the dangers facing Police Sergeant John Connolly, the officer who performed the investigatory detention. The Court noted that Sergeant Connolly "was alone early in the morning" in a "high-crime area" when he learned from an informant that "an individual seated in a nearby vehicle was carrying narcotics and had a gun at his waist." ${ }^{\text {"108 }}$ When Sergeant Connolly approached, tapped on the car window, and asked the occupant, Robert Williams, to open the door, Williams only partially complied by rolling down the window. ${ }^{109}$ Sgt. Connolly then reached into the car and "removed a fully loaded revolver from Williams' waistband." 110

${ }^{104}$ Terry, 392 U.S. at 16-17.

${ }^{105}$ Id. at 17 n. 13 .

${ }^{106} I d$. at 24.

${ }^{107}$ Adams v. Williams, 407 U.S. 143, 148 (1972).

${ }^{108}$ Id. at $144-45$.

${ }^{109} \mathrm{Id}$. at 145 .

${ }^{110} \mathrm{Id}$. 
Assessing the reasonableness of Sergeant Connolly's recovery of the gun, the Court reiterated the concern in Terry that an officer performing an investigatory stop "should not be denied the opportunity to protect himself from attack by a hostile suspect." 111 Here, the purpose of the search was not the discovery of evidence, but instead "to allow the officer to pursue his investigation without fear of violence...."112 In support of its finding that "Sgt. Connolly had ample reason to fear for his safety," 113 the Court in Adams cited "[f]igures reported by the Federal Bureau of Investigation" that "25 policemen were murdered in 1971. ..."114 Justice Rehnquist then pointed out the particular lethality of firearms, noting that "all but five" of the twenty-five officers had been killed by gunshot wounds. ${ }^{115}$ The combination of guns and cars was especially hazardous because "approximately 30\% of police shootings occurred when a police officer approached a suspect seated in an automobile." 116 Moreover, Williams's failure to comply with the Sergeant's request to "step out of the car so that his movements could be more easily seen" made the revolver an "even greater threat." 117

The fear of guns, along with the particular facts in Adams of a lone officer confronting a potentially armed stranger at 2:15 a.m., led the Court to expand the scope of the Terry search. ${ }^{118}$ The Terry Court cautioned that a frisk must be "strictly circumscribed by the exigencies which justify its initiation." 119 In that case, the Court only permitted a pat-down of outer clothing and authorized a frisk where the officer "did not place his hands in [the suspects'] pockets or under the outer surface of their garments until he had felt weapons.... ${ }^{120}$ The Court in Terry considered even this "limited search of the outer clothing for weapons" to be a "severe, though brief, intrusion upon cherished personal security...." 121 By contrast, in Adams,

${ }^{111} I d$. at 146.

${ }^{112}$ Adams, 407 U.S. at 146.

${ }^{113}$ Id. at 148

${ }^{114}$ Id. at n.3.

${ }^{115} \mathrm{Id}$.

${ }^{116} \mathrm{Id}$.

${ }^{117}$ Adams, 407 U.S. at 148.

${ }^{118}$ Id. at 144.

${ }^{119}$ Terry, 392 U.S. at 25-26.

${ }^{120} \mathrm{Id}$. at 30.

${ }^{121} \mathrm{Id}$. at 24-25. 
the Court permitted the officer to immediately reach into a car and pull a revolver from the suspect's waistband. ${ }^{122}$ Unlike Detective McFadden in Terry, Sergeant Connolly in Adams "asked no questions; he made no investigation; he simply searched." 123 The Adams Court allowed this reach-before-pat down to be based not on the officer's own observations, but on those of an informant who previously provided a tip that could not be corroborated by police. ${ }^{124}$ Thus, only four years after Terry, the prospect of a firearm being used against an officer altered both the Court's justification for, and the scope of, a frisk. ${ }^{125}$

A further extension of the scope of stop and frisks was recognized in Michigan v. Long, where the Court expanded the right to frisk to a search of the passenger compartment of a vehicle. ${ }^{126}$ In Long, patrolling deputies Howell and Lewis observed a car, which was "travelling erratically and at excessive speed," ultimately swerve into a ditch. ${ }^{127}$ When the deputies stopped to investigate, the driver of the car, Long, who "was under the influence of something," met the deputies at the rear of his car. ${ }^{128}$ After the deputies repeatedly requested a driver's license, Long walked back to his car and the officers followed. ${ }^{129}$ Both officers then observed a "large hunting knife on the floorboard of the driver's side of the car." 130 Deputy Howell, searching "for other weapons," then looked under the armrest on the front seat and found an open pouch of marijuana. ${ }^{131}$

In Long, Justice O'Connor, writing for the Court, allowed the police to "conduct an area search of the passenger compartment to

\footnotetext{
${ }^{122}$ Adams, 407 U.S. at 145.

${ }^{123} \mathrm{Id}$. at 155 (Marshall, J., dissenting).

${ }^{124} \mathrm{Id}$. at $156-57$. erosion of the Fourth Amendment.").

${ }^{126}$ Michigan v. Long, 463 U.S. 1032, 1049 (1983).

${ }^{127} \mathrm{Id}$. at 1035 .

${ }^{128} \mathrm{Id}$. at 1036 .

${ }^{129} \mathrm{Id}$.

${ }^{130} \mathrm{Id}$.

${ }^{131}$ Long, 463 U.S. at 1036.
}

${ }^{125}$ See Adams, 407 U.S. at 153 (Brennan, J., dissenting) ("[Terry v. Ohio] was meant for the serious cases of imminent danger or of harm recently perpetuated to persons or property, not the conventional ones of possessory offenses.... I greatly fear that if the [latter] is followed, Terry will have opened the sluicegates for serious and unintended 
uncover weapons." 132 The Court relied on Terry to justify the search, even though Terry "did involve the protective frisk of a person" rather than a police search of a car. ${ }^{133}$ As in Terry, the Long Court assessed the officer's reasonableness by balancing the need to search against the intrusion a search would cause. ${ }^{134}$ As it had in both Adams and Terry, the Court placed on the government's side of the balance the need for officers "to protect themselves and other prospective victims of violence" from those wielding weapons. ${ }^{135}$ The Court specified guns as evidence of the "danger presented to police officers" and again cited the study of police shootings that it relied upon in Adams. ${ }^{136}$ Additional safety issues came from the combination of weapons and cars because "vehicles are especially fraught with danger to police officers." "137 The Court in Long viewed suspects as posing a threat to police "even though they may not themselves be armed" because they could still have "access to weapons" nearby. ${ }^{138}$

Thus, the prospect of gun violence motivated the Court in Long to expand Terry in two significant respects. First, the Court extended the scope of the Terry frisk beyond a search of a suspect's person to include what it termed an "area search" of a car's passenger compartment. ${ }^{139}$ Second, the Court in Long altered the requisite police justification for a frisk by changing the focus of the threat to the police officer. While Terry required that an officer reasonably suspect that a person is "armed and presently dangerous," the Court in Long only mandated that the officer believe "the suspect is dangerous and the suspect may gain immediate control of weapons." ${ }^{140}$ The potential danger of weapons, and perhaps the danger of guns in particular, has caused not only an evolution of the original boundaries of the Terry frisk, but also, a shift in its underlying rationale.

\footnotetext{
${ }^{132}$ Id. at 1051 .

${ }^{133} \mathrm{Id}$. at 1046.

${ }^{134} \mathrm{Id}$.

${ }^{135} \mathrm{Id}$. at 1047.

${ }^{136}$ Long, 436 U.S. at 1048, n.13.

${ }^{137}$ Id. at 1047.

${ }^{138} \mathrm{Id}$. at 1048 .

${ }^{139}$ Id. at 1051 .

${ }^{140}$ Long, 436 U.S. at 1050.
} 
Moreover, perhaps the greatest impact of guns on the expansion of Terry occurred in Pennsylvania v. Mimms. ${ }^{141}$ In Mimms, police officers lawfully stopped Harry Mimms to issue him a citation for driving with an expired license plate. ${ }^{142}$ One officer approached and asked Mimms to step out of the car. ${ }^{143}$ When Mimms complied, the officer noticed a "large bulge" under the driver's jacket and the resulting frisk revealed a revolver. ${ }^{144}$ The officer had ordered Mimms out of his car even though he "did not have even the slightest hint" that he "might have a gun."145 Indeed, the officer freely admitted he had "no reason to suspect foul play from the particular driver at the time of the stop" and instead just had the practice of ordering all drivers out of the car "as a matter of course."146

The Court, in a per curiam opinion, focused on whether the "incremental intrusion" resulting from the request to get out of the car once the vehicle was lawfully stopped was permissible under the Fourth Amendment. ${ }^{147}$ Balancing the interests to determine the reasonableness of the officer's order to step out of the vehicle, the Court first weighed the government's needs in having drivers exit their vehicles. ${ }^{148}$ The State urged an officer safety rationale and contended that "establishing a faceto-face confrontation diminishe[d] the possibility, otherwise substantial, that the driver can make unobserved movements; this, in turn, reduces the likelihood that the officer will be the victim of an assault." ${ }^{149}$ The Court readily agreed, stating, "[w]e think it too plain for argument that the State's proffered justification - the safety of the officer-is both legitimate and weighty." ${ }^{150}$ To establish the need to protect officers approaching vehicles, the Court again utilized the same study on police shootings that it had relied upon in both Adams and Long. ${ }^{151}$ The Court feared for police

\footnotetext{
${ }^{141}$ Pennsylvania v. Mimms, 434 U.S. 106 (1977).

${ }^{142} I d$. at 107.

${ }^{143} \mathrm{Id}$.

${ }^{144} \mathrm{Id}$.

${ }^{145}$ Id. at 113 (Marshall, J., dissenting).

${ }^{146}$ Mimms, 434 U.S. at 109-10 (majority opinion).

${ }^{147} \mathrm{Id}$. at 109.

${ }^{148}$ Id. at $109-10$.

${ }^{149} I d$ at 110.

${ }^{150}$ Mimms, 434 U.S. at 110.

${ }^{151}$ Id. Allen P. Bristow, Police Officer Shootings-A Tactical Evaluation, 54 J. CRIM. L. CRIMINOLOGY \& POLICE SCI. 93 (1963). The study was becoming quite outdated when
} 
safety even when issuing traffic summons because, it argued, "a significant percentage of murders of police officers occurs when the officers are making traffic stops." ${ }^{\text {"152 }}$ When weighed against this "legitimate" government concern for officer safety, the driver's interest in avoiding the "inconvenience" of stepping out of the car seemed "de minimis." "153 Therefore, the Court in Mimms held that "once a motor vehicle has been lawfully detained for a traffic violation, the police officers may order the driver to get out of the vehicle" without violating the Fourth Amendment. ${ }^{154}$

In dissent, Justice Stevens found it "most disturbing" that the Court's decision was "announced almost casually, in the course of explaining the summary reversal of a decision the Court should not even bother to review." 155 Justice Stevens surmised that, "no doubt it is a legitimate concern about the safety of police officers throughout the Nation that prompts the Court to give this case such expeditious treatment." 156 At this juncture, Justice Stevens candidly revealed his own personal worries for the lives at stake; he noted, "I ... am acutely aware that almost every decision of the Court holding that an individual's Fourth Amendment rights have been invaded makes law enforcement somewhat more difficult and hazardous." 157 Despite these worries, Justice Stevens cautioned the Court against haste in deciding "every new Fourth Amendment issue as promptly as possible," because "it is of paramount importance that the Court have the benefit of differing judicial evaluations of an issue before it is finally resolved on a nationwide basis." 158

the Court cited it in Mimms. One wonders whether a lone study should single-handedly bear the burden of supporting the diminution of Fourth Amendment rights in three Supreme Court cases over fourteen years. The fact that the Court seemingly could not locate any other study in the fourteen years since the Bristow article would tend to cast doubt on the strength of its numbers; typically all science is best advanced when results can be duplicated.

${ }^{152}$ Mimms, 434 U.S. at 110.

${ }^{153}$ Id. at 111 .

${ }^{154} \mathrm{Id}$.

${ }^{155} \mathrm{Id}$. at 116 (Stevens, J., dissenting).

${ }^{156} \mathrm{Id}$. at 117.

${ }^{157}$ Mimms, 434 U.S. at 117.

${ }^{158}$ Id. 
In Mimms, the majority's rush to protect police caused the Court to get sloppy with its analysis. As previously discussed, the Court based its holding on a study that it declared proved that "approximately $30 \%$ of police shootings occurred when a police officer approached a suspect seated in an automobile." 159 A more careful review of the facts presented in the study would undermine the Court's presumption that officers could "minimize the risk of being shot" by ordering stopped drivers to exit their cars. ${ }^{160}$ The cases used in the study included instances where officers were shot while still in their own cars, shot while dismounting from their vehicles, ${ }^{161}$ or by suspects already "outside the car talking to the officer" ${ }^{\prime 162}$ - situations where a police order to exit the vehicle would either not occur or had already happened.

In its haste, the Court gave little credence to dissenting safety experts who strongly recommended that the safest option for officers should be to "never allow the violator to get out of the car."163 One of these authorities offered the following detailed advice: "In order to thoroughly protect himself as much as possible, the officer should reach with his weak hand and push the lock button down if the window is open. This will give an indication to the driver that he is to remain inside the vehicle."164 Moreover, once the driver has provided his license to the officer, "the officer should not stare at the identification but [should] return to his vehicle by backing away from the suspect car. As the patrolman backs away, he should keep his eyes on the occupant[s]."165 Although not explicitly stated, these minutely choreographed movements protect the officer from the primary danger of a shooting. The officer is to keep his front to the driver and never have his eyes leave the motorist even as he walks away from the suspect. The potential danger at such a distance

\footnotetext{
${ }^{159} I d$. at 110 (majority opinion).

${ }_{161}^{160} \mathrm{Id}$. at 118 (Stevens, J., dissenting).

${ }^{161} \mathrm{Id}$.

${ }^{162}$ Mimms, 434 U.S. at 119.

163 Id. at n.10 (Stevens, J., dissenting) (quoting VERN FOLley, POLICE PATrol TECHNIQUES AND TACTICS 95 (1973)).

${ }^{164} \mathrm{Id}$. at n. 10 (Stevens, J., dissenting) (citing August Yount, Vehicle Stops ManuAl, MiSDEMEANOR AND FELONY 2-3 (1976)).

${ }^{165}$ Id.
} 
from the motorist is not from a knife or blunt instrument, but rather, the potential danger from a gun.

The fear of firearms further eroded motorists' rights in Maryland $v$. Wilson, where the Court extended police authority to order motorists to exit a vehicle to cover passengers as well as drivers. ${ }^{166}$ Chief Justice Rehnquist, who delivered the Court's opinion, sought to bolster the government's interests with statistics. He cited the Federal Bureau of Investigation's Uniform Crime Reports and declared, "[r]egrettably, traffic stops may be dangerous encounters. In 1994 alone, there were 5,762 officer assaults and 11 officers killed during traffic pursuits and stops." ${ }^{167}$ The danger facing officers heightens because a passenger inside the vehicle "increases the possible sources of harm to the officer." threat from passengers could be better neutralized by having them exit the car because once outside, "passengers will be denied access to any possible weapon that might be concealed in the interior of the passenger compartment." 169 Therefore, the Wilson Court expanded the officer's right of suspicionless order-outs to include passengers. ${ }^{170}$

In dissent, Justice Stevens contemplated the vast implications of the Wilson ruling. Noting that "[i]n Maryland alone, there are something on the order of one million traffic stops each year," worried about the "tremendous number of routine stops that occur each day" across the nation. ${ }^{172}$ The Court's decision to allow automatic orderout of passengers would result in "the potential daily burden on thousands of innocent citizens," creating "thousands upon thousands of petty indignities" and substantially curtailing our freedom. ${ }^{173}$

In sum, during the time between Terry and Wilson, the Court's focus on weapons and the potential danger of guns motivated it to water down Fourth Amendment rights during police field investigations. By repeating the trial court's assertion that without a frisk, "the answer to the

${ }^{166}$ Maryland v. Wilson, 519 U.S. 408, 414-15 (1997).

${ }^{167} I d$. at 413.

${ }^{168} I d$.

${ }^{169} I d$. at 414 .

${ }^{170}$ Id. at $414-15$.

${ }^{171}$ Wilson, 519 U.S. 418 (Stevens, J., dissenting).

${ }^{172} I d$. at 417.

${ }^{173} I d$. at 419 . 
police officer may be a bullet, ${ }^{, 174}$ the Court in Terry sanctioned an entirely new police right to search based on information that does not rise to probable cause. ${ }^{175}$ By specifically mentioning police shootings, the Court further eroded the right of civilians in three different cases: Adams, ${ }^{176}$ Long, ${ }^{177}$ and Mimms. ${ }^{178}$ Ultimately, under Wilson, passengers who have done nothing wrong may fall under police authority; police officers maintain "unquestioned command of the situation" for no reason other than to minimize "[t]he risk of harm to both the police and the occupants. $" 179$

The threat of weapons, particularly firearms, has caused the Court to gradually erode Fourth Amendment protection against stop and frisks. Such a dynamic may only worsen with the advent of the Second Amendment as an individual right separate from militia service. The Court's decision in Heller has limited certain government regulation of guns by explicitly making certain policy choices unavailable once a constitutional right is recognized. ${ }^{180}$ The resulting increase in law enforcement's exposure to firearms may compel the Court to grant broader stop and frisk rights in order to preserve the lives of officers.

\section{The Court's Decision in Heller Could Result in Further Broadening of the Police Right of Search Incident to Arrest}

Firearms have significantly influenced the case law involving search incident to arrest. The effect occurred as early as 1969 in Chimel v. California, the Court's seminal case defining the scope of this police right to search. ${ }^{181}$ In Chimel, police officers arrested Ted Steven Chimel in his home for burglary of a coin shop. ${ }^{182}$ The officers claimed the right to

\footnotetext{
${ }^{174}$ Terry, 392 U.S. at 8.

${ }^{175} \mathrm{Id}$. at $15,24$.

${ }^{176}$ Adams, 407 U.S. at 148, n.3.

${ }^{177}$ Long, 463 U.S. at 1048, n.13.

${ }^{178}$ Mimms, 434 U.S. at 110.

179 Wilson, 519 U.S. at 414 (quoting Michigan v. Summers, 452 U.S. 692, 702-03 (1980)).

${ }^{180}$ Heller, 128 S. Ct. at 2822.

${ }^{181}$ Chimel v. California, 395 U.S. 752,763 (1969).

${ }^{182}$ Id. at 753 .
} 
search "on the basis of the lawful arrest," and then searched "the entire three-bedroom house, including the attic, the garage, and a small workshop." 183 The roughly hour-long search recovered various items, including coins. ${ }^{184}$

Justice Stewart considered the lawfulness of the search of Chimel's home and established the legal boundaries of search incident to arrest. ${ }^{185}$ The Court in Chimel ruled that,

[w]hen an arrest is made, it is reasonable for the arresting officer to search the person arrested in order to remove any weapons that the latter might seek to use in order to resist arrest or effect his escape. Otherwise, the officer's safety might well be endangered, and the arrest itself frustrated. ${ }^{186}$

The Court also allowed officers to search the arrestee's person for evidence that might be concealed or destroyed. ${ }^{187}$ Additionally, Justice Stewart declared that, "the area into which an arrestee might reach in order to grab a weapon or evidentiary items must, of course, be governed by a like rule." 188 To justify a search of this "area [of] immediate control" the Court reasoned, "[a] gun on a table or in a drawer in front of one who is arrested can be as dangerous to the arresting officer as one concealed in the clothing of the person arrested." ${ }^{189}$ Here, when offering an example of the type of weapon that officers might confront during an arrest, the Court specified a firearm, which indicates the Court's concern about the potential danger of guns during an arrest.

Guns were also a concern in United States v. Robinson, where the Court again cited the study that found that around thirty percent of shootings of officers occur when police approach a vehicle. ${ }^{190}$ In Robinson, Officer Richard Jenks arrested Willie Robinson Jr. for driving

${ }^{183} I d$. at 754 .

${ }^{184} \mathrm{Id}$.

${ }^{185} I d$. at 763 .

${ }^{186}$ Chimel, 395 U.S. at $762-63$.

${ }^{187}$ Id. at 763 .

${ }^{188} \mathrm{Id}$.

189 Id.

${ }^{190}$ United States v. Robinson, 414 U.S. 218, 234 n.5 (1973). 
with a revoked license, an offense that carried a "mandatory minimum jail term, a mandatory fine, or both." ${ }^{, 191}$ During the subsequent search incident to arrest, Jenks felt an object he could not identify in the left breast pocket of Robinson's heavy coat. ${ }^{192}$ Officer Jenks recovered a crumpled cigarette packet from Robinson's pocket and, although he "was not motivated by a feeling of imminent danger and was not specifically looking for weapons, ${ }^{, 193}$ he peered inside and found heroin. ${ }^{194}$

The Court, in an opinion written by Justice Rehnquist, candidly acknowledged that, "[v]irtually all of the statements of this Court affirming the existence of an unqualified authority to search incident to a lawful arrest are dicta." ${ }^{\prime 195}$ Despite this, the Court held that if the officer conducted a lawful custodial arrest, the Fourth Amendment permitted "a full search of the person...." ${ }^{" 196}$ Further, the Court in Robinson refused to base the "general authority" for a search incident to arrest on the likelihood that an arrestee possessed a dangerous weapon. ${ }^{197}$ Since each arrest was potentially dangerous due to "the extended exposure which follows the taking of a suspect into custody and transporting him to the police station," a general concern for officer safety provided "an adequate basis for treating all custodial arrests alike for purposes of search justification." 198 Therefore, the Court established a broad right for police to search when conducting full custodial arrests. Though the underlying rationale for allowing a search incident to arrest was "based upon the need to disarm and to discover evidence," the authority to search in any specific case did "not depend on what a court [might] later decide was the probability in a particular arrest situation that weapons or evidence would in fact be found upon the person of the suspect." ${ }^{, 199}$ Instead, a search incident to arrest was based solely on the lawfulness of the underlying arrest - if the arrest was lawful, "a search incident to the arrest require[d]

${ }^{191} I d$. at 220.

${ }^{192} \mathrm{Id}$. at 223.

${ }^{193}$ Id. at 236 n. 7 .

${ }^{194} \mathrm{Id}$. at 223.

${ }^{195}$ Robinson, 414 U.S. at 230.

${ }^{196} \mathrm{Id}$. at 235.

${ }^{197} \mathrm{Id}$. at 234.

${ }^{198}$ Id. at 234-35.

${ }^{199} I d$. at 235 . 
no additional justification." ${ }^{200}$ Thus, the valid concern for officer safety, specifically the concern for protecting officers from shooting, caused the Court not only to reaffirm the right of search incident to arrest, but also, to champion it even in relatively innocuous situations. The Court did not limit this search right to cases involving people suspected of robbery or murder, but rather extended it to the traffic offense of driving with a revoked license. Moreover, Officer Jenks's search of Robinson was upheld even though the officer searched a crumpled cigarette package, hardly a likely place for a gun or other weapons.

The tendency to articulate a bright line rule for police searches incident to arrest only hastened in New York v. Belton. ${ }^{201}$ The Belton decision involved a traffic stop where a state trooper discovered marijuana in a car occupied by four people, one of whom was Roger Belton. ${ }^{202}$ The trooper ordered each occupant out of the car, patted each one down, and "split them up into four separate areas of the Thruway" so that they would not be in physical contact with each other. ${ }^{203}$ The trooper then searched the car's passenger compartment where he found Belton's leather jacket and discovered cocaine in the pocket. ${ }^{204}$

Justice Stewart, who wrote for the Belton Court, framed the issue as whether search incident to arrest included "the passenger compartment of an automobile" in which the arrestee was riding. ${ }^{205} \mathrm{He}$ answered this question with an eye to practicality, noting that Fourth Amendment protections "can only be realized if the police are acting under a set of rules which, in most instances, makes it possible to reach a correct determination beforehand as to whether an invasion of privacy is justified in the interest of law enforcement." 206 A "single familiar standard" that was simple to understand and apply was "essential" to guide the police in

${ }^{200}$ Robinson, 414 U.S. at 235.

${ }^{201}$ New York v. Belton, 453 U.S. 454 (1980).

${ }^{202} \mathrm{Id}$. at $455-56$.

${ }^{203} I d$. at 456.

${ }^{204} \mathrm{Id}$.

${ }^{205}$ Id. at 455 .

206 Belton, 453 U.S. at 458 (quoting Wayne R. LaFave, "Case by Case Adjudication" Versus "Standardized Procedures": The Robinson Dilemma, 1974 SuP. CT. REV. 127, 142). 
avoiding Fourth Amendment violations in "their day-to-day activities."207 Since the "articles inside the relatively narrow compass of the passenger compartment of an automobile are in fact generally, even if not inevitably, within 'the area into which an arrestee might reach in order to grab a weapon or evidentiary ite[m],",208 the Court in Belton created a bright line rule: "when a policeman has made a lawful custodial arrest of the occupant of an automobile, he may, as a contemporaneous incident of that arrest, search the passenger compartment of that automobile."209

Consistent with Robinson, the Court extended this bright line rule to apply to containers found within the passenger compartment, such as Belton's jacket pocket. ${ }^{210}$ Justice Stewart conceded that, "[i]t is true, of course, that these containers will sometimes be such that they could hold neither a weapon nor evidence of the criminal conduct for which the suspect was arrested." $" 211$

Over a series of cases, therefore, the Court created and extended an absolute right to search in order to enable officers to look for weapons 1) even when they might have no reason to worry about their existence; 2) in an area that might extend beyond the arrestee's reach (the passenger compartment); and 3) where the search includes the inside of containers, such as crumpled cigarette packages, which would not be physically capable of holding the weapons or evidence which formed the basis of the search in the first place.

However, the Court was not finished with its expansion of search incident to arrest. In Thornton $v$. United States, the Court extended search incident to arrest of passenger compartments to include encounters where the officer "does not make contact until the person arrested has left the vehicle." 212 In Thornton, Officer Deion Nichols noted that the license tags on a Lincoln Town Car did not match the vehicle's make or model. ${ }^{213}$ However, before he could stop the car, its driver, Marcus Thornton, pulled

\footnotetext{
${ }^{207} \mathrm{Id}$.

${ }^{208}$ Id. at 460 (quoting Chimel v. California, 395 U.S. 752, 763 (1969)).

${ }^{209}$ Id. at 460.

${ }^{210} I d$. at 462

${ }^{211} I d$. at 461.

${ }^{212}$ Thornton v. United States, 124 S. Ct. 2127, 2129 (2004).

${ }^{213} \mathrm{Id}$.
} 
into a parking lot, parked, and exited the vehicle. ${ }^{214}$ Due to Thornton's subsequent suspicious behavior, Officer Nichols asked for consent to pat him down, which ultimately resulted in the recovery of marijuana and cocaine. $^{215}$ With probable cause to arrest, Officer Nichols handcuffed Thornton, placed him in the patrol car, and then searched the passenger compartment of the Town Car. ${ }^{216}$ During this search, Nichols found a handgun under the driver's seat. ${ }^{217}$

Chief Justice Rehnquist declared that, "[i]n all relevant aspects, the arrest of a suspect who is next to a vehicle presents identical concerns regarding officer safety and the destruction of evidence as the arrest of one who is inside the vehicle." 218 He reiterated that "[a] custodial arrest is fluid and ' $[t]$ he danger to the police officer flows from the fact of the arrest, and its attendant proximity, stress, and uncertainty.",219 The Court highlighted prior case law, which found that, "[e]very arrest must be presumed to present a risk of danger to the arresting officer." 220 The Court considered such risk "no less merely because the arrestee exited his car before the officer initiated contact, nor is an arrestee less likely to attempt to lunge for a weapon or to destroy evidence if he is outside of, but still in control of, the vehicle." 221 Finally, the Court was concerned that creating a contrary rule might prevent officers from having the discretion to "conceal their presence from a suspect until he has left his vehicle" and concluded that "[t]he Fourth Amendment does not require such a gamble." ${ }^{, 22}$ The implication of this reasoning is that limiting search incident to arrest of passenger compartments only to those encounters where an officer first initiates contact with the suspect while he is still in the vehicle would be tantamount to gambling with officers' lives.

${ }^{214} I d$.

${ }^{215} \mathrm{Id}$.

${ }^{216} I d$.

${ }^{217}$ Thornton, 124 S. Ct. at 2129.

${ }^{218}$ Id. at 2131.

${ }^{219}$ Id. (quoting United States v. Robinson, 414 U.S. 218, 234-35 (1973)).

${ }^{220}$ Id. (citing Washington v. Chrisman, 455 U.S. 1, 7 (1982)).

${ }^{221} \mathrm{Id}$. This logic is curiously inconsistent with that offered in the order-out cases, Mimms and Wilson. See supra text accompanying notes 141-73. The one continuous aspect of the Court's reasoning is the further expansion of police authority.

${ }^{222}$ Thornton, 124 S. Ct. at 2131. 
Between Chimel and Thornton, the doctrine of search incident to arrest followed a pattern of continual expansion. In order to protect lives, the Court enabled police to search an arrestee and his area of immediate control for weapons upon arrest. The area of immediate control was then expanded to automatically include the passenger compartment of all automobiles, regardless of the arrestee's actual arm length or proximity to the vehicle. Finally, in the hope of protecting police, the right to search a passenger compartment, which attached when an officer found an arrestee in a car, was extended to allow for searches even when the individual was no longer in the vehicle upon police approach. The search incident to arrest rule seemingly became a blanket right, applying even if the arrestee was already arrested, handcuffed, and placed in the back of a patrol car. ${ }^{223}$ The risk to an officer's safety in this situation was "remote in the extreme," requiring an arrestee to be "possessed of the skill of Houdini and the strength of Hercules.",224

Searches of vehicles incident to arrest went so far beyond any logical limits that further expansion became unsustainable. The breaking point came in Arizona v. Gant, which involved the arrest of Rodney Gant for driving with a suspended license. ${ }^{225}$ After Tucson police officers handcuffed Gant and locked him in the back of a patrol car, the police officers searched his car and recovered cocaine from the pocket of a jacket found in the backseat. ${ }^{226}$ The Court, in a five to four opinion authored by Justice Stevens, held that the search incident to arrest could not justify the search of Gant's vehicle. ${ }^{227}$

The Court in Gant ruled that the "Chimel rationale authorizes police to search a vehicle incident to a recent occupant's arrest only when the arrestee is unsecured and within reaching distance of the passenger compartment at the time of the search." ${ }^{, 228}$ However, the Court articulated an additional right to search incident to arrest by concluding that "circumstances unique to the automobile context also justify a search incident to a lawful arrest when it is 'reasonable to believe evidence relevant to the

\footnotetext{
${ }^{223} \mathrm{Id}$. at 2129.

${ }^{224} \mathrm{Id}$. at 2133-34 (Scalia, J., concurring).

${ }_{225}^{25}$ Arizona v. Gant, 129 S. Ct. 1710, 1714 (2009).

${ }^{226} \mathrm{Id}$.

${ }^{227} \mathrm{Id}$.

${ }^{228}$ Id. at 1719.
} 
crime of arrest might be found in the vehicle." ${ }^{229}$ It is likely that the Court added this new avenue for search incident to arrest in order to garner Justice Scalia's vote and gain a five member majority. Indeed, the "reasonable to believe" passage was lifted straight from Justice Scalia's concurrence in Thornton. ${ }^{230}$ Moreover, Justice Scalia did not conceal, in his concurring opinion in Gant, that he joined the Court's opinion solely because he was choosing the lesser of two evils. Specifically, Justice Scalia asserted, "[i]t seems to me unacceptable for the Court to come forth with a 4-to-1-to-4 opinion that leaves the governing rule uncertain."231

Justice Scalia's reasoning was explicitly informed by the danger of guns. He declared, "[1]aw enforcement officers face a risk of being shot whenever they pull a car over." 232 He noted, however, that the "risk is at its height at the time of the initial confrontation; and it is not at all reduced by allowing a search of the stopped vehicle after the driver has been arrested and placed in the squad car." 233 Since the danger of gun violence decreases once the arrestee is confined, so too should the police right to search. Here, a Supreme Court Justice specifically connected the potential danger of firearms to the scope of police invasion on Fourth Amendment rights.

What could account for the curious course of the Court's jurisprudence on search incident to arrest? The gun is a weapon that is readily available, can be fatal at a distance, and can cause death in the hands of even the inexpert, irrational, or immature. When guns - the frequent focus of the Court's fear for officer safety - are given greater protection under Heller, the need to compensate for greater availability of guns in order to save police officers' lives may result in jurisprudence further expanding search incident to arrest.

${ }^{229}$ Id. at 1713 (quoting Thornton, $124 \mathrm{~S}$. Ct. at 2137) (Scalia, J., concurring)).

${ }^{230}$ Gant, 129 S. Ct. at 1713 (quoting Thornton, 124 S. Ct. at 2137).

${ }^{231}$ Id. at 1725 (Scalia, J., concurring).

${ }^{232} I d$. at 1724.

${ }^{233} \mathrm{Id}$. (emphasis in original). 


\section{Heller Could Result in Further Limitation of Residents' Rights During Police Intrusions into the Home}

Guns have broadened legal police entry into our homes. One means of intrusion was provided by Warden $v$. Hayden, a case creating the hot pursuit exception to the warrant requirement for police entry into a house. ${ }^{234}$ In Hayden, the defendant committed armed robbery of a taxi cab company and ran away. ${ }^{235} \mathrm{Cab}$ drivers pursued the robber and reported to their dispatcher that the robber had run into a particular home, to which police responded. ${ }^{236}$ When police entered the house, they spread out throughout the home's floors. ${ }^{237}$ One officer found and arrested Hayden, who was upstairs in bed pretending to be asleep. ${ }^{238}$ Meanwhile, the other officers had recovered a "shot gun and pistol in a flush tank" and found a jacket and trousers that matched those worn by the robber in a washing machine. ${ }^{239}$

Justice Brennan, writing for the Court, found that the officers' search for an armed robber, who had entered only five minutes before, and their search "for weapons which he had used in the robbery or might use against them" were reasonable due to the "exigencies of the situation.",240 The identified emergency was that of officer safety because:

[t]he Fourth Amendment does not require police officers to delay in the course of an investigation if to do so would gravely endanger their lives or the lives of others. Speed is

\footnotetext{
${ }^{234}$ Warden v. Hayden, 387 U.S. 294 (1967). Although Warden v. Hayden does not contain the actual phrase "hot pursuit," it is recognized as the case that established this doctrine. See Terry, 392 U.S. at 20; Charles H. Whitebread \& Christopher Slobogin, Criminal Procedure: An Analysis of Cases and Concepts 224 (4th ed. 2000 ) (exploring the genesis of the "hot pursuit" doctrine in Hayden).

${ }^{235}$ Hayden, 387 U.S. at 297.

${ }^{236} \mathrm{Id}$.

${ }^{237}$ Id. at 298.

${ }^{238} I d$.

${ }^{239} I d$. Police also recovered pistol ammunition and a cap under the mattress of Hayden's bed and shotgun ammunition in a bureau drawer. These items, seemingly taken "immediately contemporaneous" with Hayden's arrest, might more properly fall under search incident to arrest. Id. at 299.

${ }^{240}$ Hayden, 387 U.S. at 298.
} 
essential, and only a thorough search of the house for persons and weapons could have insured that Hayden was the only man present and that the police had control of all the weapons which could be used against them or to effect an escape. $^{241}$

The Court championed this officer safety rule even though at least one of the officers involved failed to articulate any concern for personal safety in his testimony. ${ }^{242}$ Thus, the danger of a shot gun and pistol overrode the warrant requirement.

Furthermore, the prospect of gun violence has also changed seizures of persons during the execution of a warrant in the suspect's home. In Michigan $v$. Summers, police officers were about to execute a narcotics search warrant on Summers's house when they encountered him going down the front steps. ${ }^{243}$ The officers detained Summers while searching his home and ultimately arrested him when they discovered narcotics in his basement. ${ }^{244}$ As a result of a search upon arrest, police recovered heroin in Summers's coat pocket. ${ }^{245}$ Summers moved to suppress the heroin in his pocket, arguing that the "initial detention" of his person was unlawful. ${ }^{246}$ Justice Stevens, writing for the Court, noted that, in order to assess the reasonableness of such a seizure, the Court must consider the "substantial law enforcement interests" justifying it. ${ }^{247}$ The Court underscored the interest of "minimizing the risk of harm to officers" as an important consideration. ${ }^{248}$ Conceding that the record in this case indicated "no special danger to the police," Justice Stevens still worried that "the execution of a warrant to search for narcotics is the kind of transaction that may give rise to sudden violence or frantic efforts to

${ }^{241} I d$. at $298-99$.

${ }^{242} \mathrm{Id}$. at 299-300 (noting that the officer in question testified that he was searching for "the man or the money").

${ }^{243}$ Michigan v. Summers, 452 U.S. 692, 693 (1980).

${ }^{244}$ Id.

${ }^{245} \mathrm{Id}$.

${ }^{246} I d$. at 694.

${ }^{247}$ Id. at 699.

${ }^{248}$ Summers, 452 U.S. at 702. 
conceal or destroy evidence." 249 The Court therefore determined that the "risk of harm to both the police and the occupants is minimized if the officers routinely exercise unquestioned command of the situation." 250 The Court addressed concerns about rapidly evolving and tense situations, such as a warrant execution on the home, by granting complete authority to officers.

The Court made an even more explicit connection between the danger of weapons in the home and the need to grant total command authority to police in Muehler v. Mena. ${ }^{251}$ In Muehler, while investigating a gang-related drive-by shooting, Officers Muehler and Brill obtained a warrant to search a home where Iris Mena resided. ${ }^{252}$ Due to "the high degree of risk involved in searching a house suspected of housing at least one, and perhaps multiple, armed gang members, a Special Weapons and Tactics (SWAT) team was used to secure the residence and grounds before the search." ${ }^{253}$ In the course of executing the warrant, the SWAT team entered Iris Mena's bedroom and "placed her in handcuffs at gunpoint." ${ }^{254}$ She and three other individuals arrested in the house were placed in a converted garage, under the watch of police officers for two to three hours. ${ }^{255}$ Mena sued the officers for unreasonably detaining her in violation of the Fourth Amendment. ${ }^{256}$

Assessing the legality of seizing Mena's person, the Court followed Summers, concluding that "minimizing the risk of harm to the officers" justified the detention. ${ }^{257}$ The Court determined that "[t]he governmental interests in not only detaining, but using handcuffs, are at their maximum when, as here, a warrant authorizes a search for weapons and a wanted gang member resides on the premises." 258 Chief Justice Rehnquist characterized the situation as "inherently dangerous"

${ }^{249} \mathrm{Id}$.

${ }^{250}$ Id. at $702-03$.

${ }^{251}$ Muehler v. Mena, 544 U.S. 93 (2005).

${ }^{252} I d$. at $95-96$.

${ }^{253}$ Id. at 96.

${ }^{254} \mathrm{Id}$.

${ }^{255} I d$. at $96,100$.

${ }^{256}$ Muehler, 544 U.S. at 96.

${ }^{257} \mathrm{Id}$. at 98,100 .

${ }^{258} I d$. at 100.

${ }^{259} \mathrm{Id}$. 
emphasized that, among the items taken, police recovered the following weapons: "a .22 caliber handgun with .22 caliber ammunition, a box of .25 caliber ammunition, (and) several baseball bats with gang writing." 260 The presence of weapons combined with multiple occupants in the home increased the danger facing officers. ${ }^{261}$

Thus, in these three cases, the Court limited the Fourth Amendment rights of residents in private homes in order to avoid sending police into houses unguarded against armed ambush. The potential danger of being surprised by firepower when chasing a criminal into a home, or executing a warrant in a home, could be even greater after Heller, which barred several restrictions on guns. ${ }^{262}$ As a result, the Court may try to protect police officers in the future by further limiting the Fourth Amendment rights of homeowners.

E. The Heller Court's fear that Enumerated Constitutional Rights Could Be Subjected to a Freestanding 'InterestBalancing' Approach Is Glaringly Inconsistent with the Court's Fourth Amendment Precedent

As part of its Second Amendment analysis, the Heller Court considered criticism offered by Justice Breyer in his dissenting opinion. As Justice Scalia characterized it, Justice Breyer proposed a "judgeempowering 'interest-balancing inquiry' that 'asks whether the statute burdens a protected interest in a way or to an extent that is out of proportion to the statute's salutary effects upon other important governmental interests." "263 Justice Scalia provided a less than charitable summary of Justice Breyer's application of this newly minted interestbalancing test:

[a]fter an exhaustive discussion of the arguments for and against gun control, Justice BREYER arrives at his interestbalanced answer: because handgun violence is a problem,

\footnotetext{
${ }^{260} I d$. at 96.

${ }^{261}$ Muehler, 544 U.S. at 100.

${ }^{262}$ Heller, 128 S. Ct. at 2822.

${ }^{263}$ Id. at 2821 (quoting Heller, 128 S. Ct. at 2852 (Breyer, J., dissenting)).
} 
because the law is limited to an urban area, and because there were somewhat similar restrictions in the founding period (a false proposition that we have already discussed), the interest-balancing inquiry results in the constitutionality of the handgun ban. QED. ${ }^{264}$

In challenging Justice Breyer's approach, the Heller Court flatly announced, "[w]e know of no other enumerated constitutional right whose core protection has been subjected to a freestanding 'interest-balancing' approach.."265 Justice Scalia then categorically declared:

[t]he very enumeration of the right takes out of the hands of government - even the Third Branch of Government- the power to decide on a case-by-case basis whether the right is really worth insisting upon. A constitutional guarantee subject to future judges' assessments of its usefulness is no constitutional guarantee at all. ${ }^{266}$

The Court's resulting logic was quite simple: the Second Amendment's right to bear arms, because it was specifically included in the Constitution as an enumerated right, has already survived a balancing analysis by its drafters, and therefore, should be immune from any further balancing by the courts. According to Justice Scalia, the Court has refused to allow such balancing of interests to erode any other specifically enumerated right, so it should treat the Second Amendment with no less deference.

The Heller Court's blanket denouncement of the balancing of interests involving an enumerated right demonstrates a perplexing case of amnesia. In the very same opinion that the Court denies its record of limiting the scope of specific constitutional rights through a balancing of interests analysis, the Court also mentions the Fourth Amendment ${ }^{267}$-an

\footnotetext{
${ }^{264} I d$.

${ }^{265} \mathrm{Id}$.

${ }^{266} \mathrm{Id}$.

${ }^{267}$ The Heller Court noted, "[t]he first salient feature of the operative clause is that it codifies a 'right of the people.' The unamended Constitution and the Bill of Rights used the phrase 'right of the people' two other times, in the First Amendment's Assembly-and-
} 
enumerated right that has suffered dramatic erosion through the Court's use of just such a balancing analysis.

For example, the Court in Terry advocated the balancing of interests inquiry when it assessed the reasonableness of the officer's conduct. $^{268}$ In Terry the Court instructed,

[i]n order to assess the reasonableness of Officer McFadden's conduct as a general proposition, it is necessary "first to focus upon the governmental interest which allegedly justifies official intrusion upon the constitutionally protected interest of the private citizen," for there is "no ready test for determining reasonableness other than by balancing the need to search [or seize] against the invasion which the search [or seizure] entails."269

The resulting balancing test was employed to allow police to seize a person based on information constituting less than the traditional standard of probable cause $\mathrm{e}^{270}$ and to frisk individuals even when lacking probable cause for arrest. ${ }^{271}$

Moreover, the balancing of interests analysis was used in United States v. Martinez-Fuerte to further diminish Fourth Amendment rights. ${ }^{272}$ This case involved Border Patrol immigration investigations at permanent checkpoints. Although recognizing that "[ $\mathrm{t}]$ he Fourth Amendment imposes limits on search-and-seizure powers in order to prevent arbitrary and oppressive interference by enforcement officials with the privacy and personal security of individuals," the Court still submitted to a balancing of "the public interest against the Fourth Amendment interest of the individual." ${ }^{273}$ As a result, the Court in Martinez-Fuerte abandoned not only the requirement of probable cause for seizure of vehicles, but also the

Petition Clause and in the Fourth Amendment's Search-and-Seizure Clause." Id. at 2790 (quoting U.S. CONST. amend. II).

${ }^{268}$ See Terry, 392 U.S. at 20-21.

${ }^{269} I d$.

${ }^{270}$ See id. at 21.

${ }^{271}$ See id. at 24.

${ }^{272}$ United States v. Martinez-Fuerte, 428 U.S. 543, 552-53 (1976).

${ }^{273}$ Id. at 554-55. 
requirement of reasonable suspicion because it would be "impractical because the flow of traffic tends to be too heavy to allow the particularized study of a given car that would enable it to be identified as a possible carrier of illegal aliens. ${ }^{274}$ Within this balance-the-interests context, the Court even ventured to state that "the Fourth Amendment imposes no irreducible requirement" of individualized suspicion. ${ }^{275}$ The latter is quite a departure from the Terry Court's reluctance to adopt a standard less than probable cause. The rejection of an individualized suspicion requirement because of worries about traffic congestion seems to be the very kind of analysis that the Court in Heller condemned because it left constitutional guarantees vulnerable to judges' current assessments of a right's "usefulness." 276 Yet instead of correcting its error by changing the rule in Martinez-Fuerte, the Court affirmed this rule over a dozen years later in Michigan Dep't of State Police v. Sitz, a case in which the Court balanced interests of police and civilians during the seizure of motorists at sobriety checkpoints. $^{277}$

Perhaps the most dramatic restriction of Fourth Amendment protection by interest balancing occurred in the context of what the Court labeled "special needs." 278 An early special needs case, New Jersey $v$. T.L.O., involved a public school assistant vice principal who recovered marijuana from a student's purse. ${ }^{279}$ The T.L.O. Court balanced the school officials' interest in maintaining classroom discipline against the student's privacy interest in an article she carried on campus. The Court concluded that the Fourth Amendment could be satisfied without resort to either probable cause or a warrant. ${ }^{280}$

Special needs balancing later justified even greater privacy intrusions. In Skinner v. Railway Labor Executives Ass'n, the Court upheld drug testing of railroad employees' blood, breath, and urine as reasonable

\footnotetext{
${ }^{274} \mathrm{Id}$. at 557.

${ }^{275} \mathrm{Id}$. at 560-61.

276 Justice Scalia opined, “[a] constitutional guarantee subject to future judges' assessments of its usefulness is no constitutional guarantee at all." Heller, $128 \mathrm{~S}$. Ct. at 2821.

${ }^{277}$ Michigan Dep't of State Police v. Sitz, 496 U.S. 444, 450 (1990).

${ }^{278}$ New Jersey v. T.L.O., 469 U.S. 325, 351 (1985) (Blackmun, J., concurring).

${ }^{279} \mathrm{Id}$. at 328 .

${ }^{280}$ Id. at $340-43$.
} 
under the Fourth Amendment. ${ }^{281}$ Writing for the Skinner Court, Justice Kennedy determined that railroad safety implicated "special needs" beyond normal law enforcement," 282 which made "the warrant and probable-cause requirement impracticable."283 Balancing the competing interests, the Court in Skinner placed railroads on par with "nuclear power facilities," and found the government interest in suspicionless drug testing of railroad workers to be "compelling." ${ }^{.284}$ Collecting biological samples was seen as "commonplace in these days of periodic physical examinations" 285 and therefore was merely "routine in our everyday life.".286

The Court struck a similar balance of interests when it reduced Fourth Amendment protections in Treasury Employees v. Von Raab, a case that examined drug testing of Customs Service employees who were involved in drug interdiction, the carrying of firearms, or the handling of classified material. ${ }^{287}$ Applying special needs balancing, the Court in Von $R a a b$ viewed the government interest as one confronting extreme dangers, warning of "extraordinary safety and national security hazards" and deeming drug abuse to be "one of the most serious problems confronting our society today." 288 The Court worried about "drug users" carrying firearms ${ }^{289}$ and speculated about the risk of employees, "who may suffer from impaired perception and judgment," using deadly force. ${ }^{290}$ Such official concerns outweighed the "privacy concerns implicated by the tests," and therefore the Court in Von Raab found it reasonable to allow drug testing of employees interdicting drugs or carrying firearms, even without the traditional Fourth Amendment safeguards of a warrant or individualized suspicion. ${ }^{291}$

The most dramatic example of the Court's use of balancing interests analysis to limit Fourth Amendment rights occurred in Vernonia

${ }^{281}$ Skinner v. Railway Labor Executives’ Ass'n, 489 U.S. 602, 606 (1988).

${ }^{282} I d$. at 620 .

${ }^{283} \mathrm{Id}$. at 619 .

${ }^{284} I d$. at 628 .

${ }^{285}$ Id. at 625 (quoting Schmerber v. California, 384 U.S. 757, 771 (1966)).

${ }^{286}$ Skinner, 489 U.S. at 625 (quoting Breithaupt v. Abram, 352 U.S. 432, 436 (1957)).

${ }^{287}$ Treasury Employees v. Von Raab, 489 U.S. 656, 660-61 (1988).

${ }^{288} I d$. at 674 .

${ }^{289} \mathrm{Id}$.

${ }^{290} I d$. at 671 .

${ }^{291}$ Id. at 679 . 
School District $47 J$ v. Acton, an opinion authored by Justice Scalia. ${ }^{292}$ In response to an increase in drug use that occasioned student discipline problems, such as rudeness, profanity, and sports-related injury, school officials in Vernonia, Oregon implemented a drug testing program of student athletes. ${ }^{293}$ All students who wished to participate in interscholastic athletics were compelled to submit to drug testing at the beginning of their sport's season and to random testing throughout the season. ${ }^{294}$ Teachers of the same sex as the student were present in the bathroom to monitor the collection of urine samples. ${ }^{295}$ James Acton, a seventh grader who wished to play football, was denied participation in school sports when he refused to turn in signed consent forms for urinalysis. ${ }^{296} \mathrm{He}$ then sued the school district on Fourth Amendment grounds. ${ }^{297}$

Writing for the Court, Justice Scalia noted that, "where there was no clear practice, either approving or disapproving the type of search at issue, at the time the constitutional provision was enacted," the Court must measure the reasonableness of the search by balancing the interests of the government and the individual. ${ }^{298}$ Justice Scalia applied a balancing formula to assess the reasonableness of the Vernonia drug testing program, listing three factors to consider: "the decreased expectation of privacy, the relative unobtrusiveness of the search, and the severity of the need met by the search., ${ }^{299}$ In considering the first factor regarding privacy expectations or interests, the Court examined two issues: 1) the place where the student asserts his privacy interest, and 2) "the individual's legal relationship with the State." 300 In terms of the unobtrusiveness of the search, the Court looked at 1) the "manner" in which the sample was collected, and 2) the information the urinalysis disclosed. ${ }^{301}$ Finally,

\footnotetext{
${ }^{292}$ Vernonia Sch. Dist. 47J v. Acton, 515 U.S. 646 (1995).

${ }^{293}$ Id. at $648-49$.

${ }^{294} I d$. at 650.

${ }^{295} \mathrm{Id}$.

${ }^{296} I d$. at 651.

${ }^{297} \mathrm{Id}$.

${ }^{298}$ Vernonia, 515 U.S. at 652-53.

${ }^{299} \mathrm{Id}$. at 664-65.

${ }^{300} \mathrm{Id}$. at 654 .

${ }^{301} I d$. at 658 .
} 
the third balancing factor was divided into three sub-factors: 1) the nature of the governmental interest, ${ }^{302}$ 2) the immediacy of the government's concern,, 303 and 3) the "efficacy of [the] means for addressing the problem." 304

In addition to balancing these multi-faceted factors (none of which appear in the text of the Fourth Amendment), the Court required the assessment of the free-floating "most significant element," which was defined as the government's role "as guardian and tutor." 305 After balancing these interests, the Court found that requiring James Acton to submit to a drug test did not violate his Fourth Amendment rights. ${ }^{306}$ Fourth Amendment balancing has also been applied to uphold mandatory drug testing for a variety of extracurricular activities, including band, choir, Future Farmers of America and Future Homemakers of America. ${ }^{307}$

Justice Scalia's concern that a balancing test would erode Second Amendment rights in the Heller opinion is unsurprising, given the status of Fourth Amendment rights after Vernonia. The technique of balancing Fourth Amendment interests expanded beyond its origin as a confined exception and became the norm in assessing checkpoint stops, and urinalysis of railroad workers, government employees, and students involved in a host of extracurricular activities. The Court has also employed balancing of interests in such unrelated contexts as housing inspections, ${ }^{308}$ junkyard regulatory inspections, ${ }^{309}$ and probation searches. ${ }^{310}$ By 2001 , the balancing test had officially become the rule rather than the exception. ${ }^{311}$ Without even referring to the need for a warrant or probable cause, the Court in United States $v$. Knights announced, "[t]he touchstone of the Fourth Amendment is reasonableness and the reasonableness of a search is determined by assessing, on the one hand, the degree to which it

\footnotetext{
${ }^{302}$ Id. at 660 .

${ }^{303}$ Vernonia, 515 U.S. at 660.

${ }^{304}$ Id. at 663 .

${ }^{305} \mathrm{Id}$. at 665 .

${ }^{306} I d$. at 664-65.

${ }^{307}$ Bd. of Educ. v. Earls, 122 S. Ct. 2559, 2562-63 (2002).

${ }^{308}$ Camara v. Mun. Court, 387 U.S. 523, 534-35 (1966).

${ }^{309}$ New York v. Burger, 482 U.S. 691, 699-703 (1987).

${ }^{310}$ United States v. Knights, 534 U.S. 112, 118-19 (2001).

${ }^{311}$ Id.
} 
intrudes upon an individual's privacy and, on the other, the degree to which it is needed for the promotion of legitimate governmental interests. ${ }^{312}$

Thus, the prospect of balancing interests for specifically enumerated constitutional rights - the danger that Justice Scalia feared in Heller $^{313}$ - has already occurred in the Fourth Amendment context. Moreover, the Supreme Court has already justified its diminution of Fourth Amendment protections in part because of the fear of firearms falling into the wrong hands. ${ }^{314}$ Yet the increased risk of gun violence itself is a potential consequence of the Supreme Court's robust reading of the Second Amendment in Heller.

\section{CONCLUSION}

Be careful what you wish for, because you just might get it. For years, there has been a vehement call for recognition of the Second Amendment as an individual right rather than as a collective right premised on the duty to field militias. ${ }^{315}$ In Heller, the Supreme Court finally resolved the issue, ruling definitively that the "Second Amendment conferred an individual right to keep and bear arms. ${ }^{, 316}$ In order to remove any doubt, the Court issued a thirty-six page opinion, meticulously analyzing the text of the Amendment ${ }^{317}$ and comprehensively reviewing

\footnotetext{
${ }^{312} I d$. (internal citations and punctuation omitted).

${ }^{313}$ Heller, 128 S. Ct. at 2821.

${ }^{314}$ Von Raab, 489 U.S. at 670-71.

${ }^{315}$ See generally Sanford Levinson, The Embarrassing Second Amendment, 99 YALE L.J. 637 (1989); Scott A. Henderson, United States v. Emerson: The Second Amendment as an Individual Right-Time to Settle the Issue?, 102 W. VA. L. REv. 177 (1999); Roland H. Beason, Printz Punts on the Palladium of Rights: Is It Time to Protect the Right of the Individual to Keep and Bear Arms?, 50 ALA. L. REv. 561 (1999); Jerry Bonanno, Facing the Lion in the Bush: Exploring the Implications of Adopting an Individual Rights Interpretation of the Second Amendment to the United States Constitution, 29 HAMLINE L. REv. 461 (2006); and Christopher A. Chrisman, Mind the Gap: The Missing Standard of Review Under the Second Amendment (and Where to Find It), 4 GeO. J.L. \& PuB. POL'Y 289 (2006).

${ }^{316}$ Heller, 128 S. Ct. at 2799.

${ }^{317}$ Id. at $2788-802$.
} 
the history of the individual right to keep and bear arms dating back to the time of the Stuart kings. ${ }^{318}$

Yet, as discussed above, expanding gun rights may consequently impede individual rights that are arguably even more central to liberty: the Fourth Amendment's freedom from government intrusions into individual privacy and personal security. In supporting the interpretation later adopted by the Supreme Court, Judge Kozinski described the Second Amendment not only as an individual right, but also as a "doomsday provision" to use in "those exceptionally rare circumstances where all other rights have failed." ${ }^{319}$ In other words, he believed that the Framers recognized that the individual's right to keep and bear arms was essential to protect the rights conferred by the Constitution. Yet, a situation necessitating armed rebellion against our own government in order to ensure the enforcement of the rights guaranteed by the Constitution is difficult to fathom. A much more likely and imminent threat to individual liberty is the slow erosion of rights, including and especially the narrowing of Fourth Amendment protections, as outlined throughout this article. Fearing the daily dangers that officers face from guns, the Court is likely to continue to support broader law enforcement searching powers. In this incremental fashion, the Fourth Amendment is weakened by "thousands upon thousands of petty indignities." 320

Police are, of course, endangered by a variety of weapons besides firearms. Even a partial listing offered by the Court over a century ago sounds ominous: "a dirk, a knife, a sword cane, a slung shot, or a club." 321 These weapons certainly pale in comparison to the various weapons used today. Thus, guns are not the only threat the Court considers when it crafts rules guarding officer safety. Still, with its danger at a distance, its convenience, its ease of use, and its ubiquity, the gun must play a major role in the Justices' decision-making. This is borne out by the Court's own language. The Court in Terry refused to spare every citizen on the street

\footnotetext{
${ }^{318}$ Id. at $2798-99$.

${ }^{319}$ Chrisman, supra note 31, at 301 (quoting Silveira v. Lockyer, 328 F.3d 567, 570 (2003) (Kozinski, J., dissenting)).

${ }^{320}$ See Wilson, 177 S. Ct. at 888 (Stevens, J., dissenting).

${ }^{321}$ Robinson, 414 U.S. at 231.
} 
from the "indignity",322 of being frisked, proclaiming that "[t]here is no reason why an officer ... should have to ask one question and take the risk that the answer might be a bullet." ${ }^{323}$ In sanctioning police intrusions as varied as grabbing a gun from a waistband, ${ }^{324}$ frisking the passenger compartment of a vehicle for weapons, ${ }^{325}$ ordering out occupants of vehicles, ${ }^{326}$ and searching incident to arrest, ${ }^{327}$ the Court voiced a special concern about "shootings." The existence of a "shot gun and a pistol in a flush tank" prompted the Court to create the hot pursuit exception for police intrusions into the home, ${ }^{328}$ and a .22 caliber handgun steered the Court to uphold the seizure and handcuffing of a person in a house searched pursuant to a warrant. ${ }^{329}$ Indeed, gun violence was such a focal point for the Court that it limited Fourth Amendment rights four times on the basis of a single scientific study of police officer shootings. ${ }^{330}$

In Heller, the Court made the powerful declaration that the Second Amendment is an individual right that "takes certain policy choices off the table." ${ }^{331}$ The government's options to proactively address the existence, proliferation, and use of guns will inevitably be restricted, and thus it must rely more heavily on a reactive approach. The expansion of gun rights will pressure the Court to further limit Fourth Amendment freedoms against search and seizure in order to protect the lives of police officers. Thus, its

\footnotetext{
${ }^{322}$ Terry, 392 U.S. at 17. In Minnesota v. Dickerson, Justice Scalia himself volunteered the doubt that the "fiercely proud men who adopted our Fourth Amendment would have allowed themselves to be subjected, on mere suspicion of being armed and dangerous, to such indignity." Minnesota v. Dickerson, 113 S. Ct. 2130, 2140 (1993) (Scalia, J., concurring) (emphasis in original).

${ }^{323}$ Terry, 392 U.S. at 33.

${ }^{324}$ Adams, 407 U.S. at 148 n.3.

${ }^{325}$ Long, 463 U.S. at 1046 n. 13.

${ }^{326}$ Mimms, 434 U.S. at 110.

${ }^{327}$ Robinson, 414 U.S. at 234 n.5.

${ }^{328}$ Warden, 387 U.S. at 298.

${ }^{329}$ Muehler, 544 U.S. at 96.

${ }^{330}$ The Court cited Allen P. Bristow, Police Officer Shootings-A Tactical Evaluation, 54 J. Crim. L.C. \& P.S. 93 (1963), for the fact that "approximately $30 \%$ of police shootings occurred when a police officer approached a suspect seated in an automobile." See Adams, 407 U.S. at 148 n.3; Long, 463 U.S. at 1046 n.13; Mimms, 434 U.S. at 110; Robinson, 414 U.S. at 234 n.5.

${ }^{331}$ Heller, 128 S. Ct. at 2822.
} 
promotion of the right to possess a gun will cause the Court to further fear the bullet. 